‘QUO VADIS' CHURCH HISTORY / ECCLESIOLOGY?

\title{
A RESPONSE
}

Lisel Joubert

DRC Gansbaai

It is a privilege to have the opportunity to think about the future of theology as an academic discipline and especially on the role of Ecclesiology (Church History). I will do it by just briefly making some comments on all five theses as were set on the table by Dr Vosloo. The comments are not extensive but rather reflects my own personal and passionate beliefs, and I will jump from the perspective of students, church leaders and my own position as lover of history.

Firstly just a general remark in support of this specific theological discipline. The participants in this "Quo Vadis?" conference would not have understood the purpose of such a conference if they did not have the historical knowledge which explains this question "Quo Vadis?" as part of Christian tradition! History is also important in the answering of this age old question for each discipline, because the responsible plotting of direction for the future needs a honest appraisal of the past and insight into past methods of doing. Without history no discipline can look at the future meaningfully. Christianity is al about past events which gives meaning to the present and creates hope for the future.

Dr Vosloo's first thesis is: "the vitality of Church History as an academic discipline is linked to its ability to contribute towards a responsible engagement with the Christian past in a culture of historical amnesia a harmful memory."

I would like to respond from the perspective of students that learn Church History in order to become part of church communities and take on the role of church leaders. The learning of history does not always entail the learning of skills to interpret history in a specific context. Also, the compulsory study of history does not, sadly, always lead to a curiosity to understand your own past better. A healthy curiosity is necessary for the building of relationships in our country, where newly appointed ministers can enter communities and be experienced as women and men who in a healthy manner honour everybody's past. To be specific the Dutch Reformed Church needs leaders who want to move from amnesia (as well as a crooked sense of history) into a positive future, always mindful of the past.

From the perspective of church leaders history also brings a healthy relativity. It reminds us that a lot of the theological and other issues or debates we deal with has happened in the past and will happen again. A knowledge of history will enable church leaders to act wisely in midst of doctrinal and ecclesiological disputes, learning from the past and putting issues in perspectives.

Church History as an academic discipline also needs the honing of skills needed to read and interpret primary and secondary sources. Especially at the University of Stellenbosch where the archive of the Dutch Reformed Church is found next to the faculty immense research possibilities are open, which would help 'rewrite' the history of Christianity in South Africa in a more balanced manner.

Historical curiosity or inquisitiveness needs specialised hermeneutical skills as Dr Vosloo pleads for in his second thesis. Here he reminds us that responsible historical study needs the methods of social sciences and necessary interdisciplinary work in theology as well. Responsible and meaningful academic exercises needs to go beyond the sometimes stifling boundaries of the different disciplines. Linking this thought with that in his third 
thesis, that history is not only the history of princes and kings but of the ordinary people through the ages. This is the reminder that history has many times forgotten "her" story, being biased towards ecclesiological power and gender.

Alongside the above, doing Church History in the future, needs to take into account the universal character of the church. History cannot only be a means of furthering a specific agenda from the past. An example would suffice: "Ons glo dat Christus die Koning van die kerk die geskiedenis volgens ' $n$ vaste plan na ' $n$ bepaalde einde laat ontwikkel...Ons moet in die Kergeskiedenis die vaste lyn probeer ontdek, die leidende gedagte te midde van al die worsteling en stryd van die kerk....As ons die leidende gedagte wil volg kan ons nie neutral wees nie, ons moet kant kies...In watter een van die baie kerke van vandag vind ons nog die suiwere leer?" 1

The above (questionable) statement understands the primary goal of Church History as the identification of the most orthodox doctrine. I hope that Church History as an academic discipline will be more than the standing on a doctrinal moral high ground, but will be amongst other things an exercise in listening to voices, past and present, as well as the appreciating of the richness of the multitude of traditions. As a theological discipline, a teleology is always present but hopefully not exclusive.

In the placing of Church History in a theological curriculum one finds many overlapping interests with other disciplines, for example: history of missions, history of the Bible, history of spirituality etc. which can be fruitfully explored. Especially here the hermeneutic skills of readings sources can be shared amongst disciplines.

The fourth thesis of Dr Vosloo is a reminder of the ideological nature of our mapping habits. This is important for doing theology in Africa. Without falling into the trap of Afrocentrism, it is wise to remember in a post colonial Africa, that the roots of Christianity in Africa are older than the arrival of the European colonists. Africa is the cradle of monasticism and home of many important Church fathers. A faculty that teaches Church History in South Africa has to work more broadly than South African Church History and that of the Western world. The story of the Church in our continent is a rich story that needs to be heard for future healing. With that I also refer to the last thesis of Dr Vosloo, namely the reminder that shared history has the potential of a new creative historiography widening our horizons but also our understanding of our own identity.

I would like to end with the existential realisation that history can sometimes be "just too much". In his novel "Measuring the World" the German writer Daniel Kehlman has two main characters whose lives interacts namely the mathematician Gauss and Alexander von Humboldt. At one stage Von Humboldt is travelling in South America and is visiting the ruins of an Aztec temple. Somebody tells him how twenty thousand people stood in rows to be sacrificed with the consecration of the temple. Their hearts were cut out and their heads chopped off. Von Humboldt reacted: "The victims would never tolerate it. What was more the world order would not support it. If such a thing ever happened, the universe would come to an end."

Church History surprises us that the universe is still standing at all but in a sense presents the insights for a more righteous future. 